\title{
Polyphasic Characterization of Xanthomonas Strains from Onion
}

\author{
David H. Gent, Howard F. Schwartz, Carol A. Ishimaru, Frank J. Louws, \\ Robert A. Cramer, and Christopher B. Lawrence
}

First, second, third, and fifth authors: Department of Bioagricultural Sciences \& Pest Management, Colorado State University, Fort Collins 80523; fourth author: Department of Plant Pathology, North Carolina State University, Raleigh 27695; and sixth author: Virginia Bioinformatics Inst., Virginia Tech, Blacksburg 24061.

Accepted for publication 18 September 2003.

\begin{abstract}
Gent, D. H., Schwartz, H. F., Ishimaru, C. A., Louws, F. J., Cramer, R. A., and Lawrence, C. B. 2004. Polyphasic characterization of Xanthomonas strains from onion. Phytopathology 94:184-195.

Xanthomonas leaf blight has become an increasingly important disease of onion, but the diversity among Xanthomonas strains isolated from onion is unknown, as is their relationship to other species and pathovars of Xanthomonas. Forty-nine Xanthomonas strains isolated from onion over 27 years from 10 diverse geographic regions were characterized by pathogenicity to onion and dry bean, fatty acid profiles, substrate utilization patterns (Biolog), bactericide resistance, repetitive sequencebased polymerase chain reaction fingerprinting, rDNA internally transcribed spacer (ITS) region, and $h r p$ b6 gene sequencing. Multiplication of onion Xanthomonas strain R-O177 was not different from X. axonopodis pv. phaseoli in dry bean, but typical common bacterial blight disease symptoms were absent in dry bean. Populations from each geographical region were uniformly sensitive to $100 \mu \mathrm{g}$ of $\mathrm{CuSO}_{4}, 100 \mu \mathrm{g}$ of $\mathrm{ZnSO}_{4}$, and $100 \mu \mathrm{g}$ of streptomycin sulfate per ml. Biolog substrate
\end{abstract}

ABSTRACT

A leaf blight of onion caused by Xanthomonas (Pammel) Dowson strains has appeared as a major disease of onion since it was first described in Hawaii in 1978 (2). Disease symptoms are varied and include leaves with lenticular water-soaked lesions that elongate into chlorotic streaks, necrosis, tip dieback, and stunting of plants, which reduces bulb size. A bulb rot has never been reported and apparently does not occur, but yield losses of 19 to $100 \%$ have been reported $(26,29,37)$.

Since its original description by Alvarez et al. (2), the disease has been reported in Texas (14), Colorado (36), California (26), Barbados (29), South Africa (38), Reunion Island, France (34), and Georgia (35). Unreported epidemics of the disease have also been observed in Venezuela and Brazil (R. Gitaitis, personal communication). A similar disease caused by strains classified as $X$. striaformans was reported on onion in southern Colorado in 1953 (40), but differed in 8 of 18 physiological characteristics from the Xanthomonas sp. described by Alvarez et al. (2). A bacterial blight of Welsh onion (Allium fistulosum L.) classified as X. campestris pv. allii has also been described in Japan (16), but its relationship to other strains causing disease on A. cepa $\mathrm{L}$. is unknown.

The host range of Xanthomonas isolated from onion remains uncertain. Strains from Barbados are reportedly pathogenic to leguminous hosts such as snap bean (Phaseolus vulgaris L.), lima

Corresponding author: H. F. Schwartz

E-mail address: Howard.Schwartz@ colostate.edu

Publication no. P-2003-1201-01R

(C) 2004 The American Phytopathological Society utilization and fatty acid profiles revealed close phenoltypic relatedness between onion strains of Xanthomonas and X. axonopodis pv. dieffenbachiae (57\% of strains) and X. arboricola pv. poinsettiicola (37\% of strains), respectively. A logistic regression model based on fatty acid composition and substrate utilization classified $69 \%$ of strains into their geographical region of origin. Sequencing of a portion of the hrp B6 gene from 24 strains and ITS region from 25 strains revealed greater than $97 \%$ sequence similarity among strains. DNA fingerprinting revealed five genotype groups within onion strains of Xanthomonas and a high degree of genetic diversity among geographical regions of origin. Based on pathogenicity to onion, carbon substrate utilization, fatty acid profiles, rDNA genetic diversity, and genomic fingerprints, we conclude that the strains examined in this study are pathovar $X$. axonopodis pv. allii. Implications of genetic and phenotypic diversity within $X$. axonopodis pv. allii are discussed in relation to an integrated pest management program.

Additional keywords: Allium cepa, Allium fistulosum, Capsicum annuиm, Phaseolus vulgaris.

bean (Phaseolus lunatus L.), soybean (Glycine max (L.) Merr.), winged bean (Psophocarpus tetragonolobus (L.) DC.), moth bean (Vigna aconitifolia (Jacq.) Marechal), and field pea (Pisum sativum L.) (27), as well as other Allium spp. including leek (A. ampeloprasum var. porrum L.), chives (A. schoenoprasum L.), garlic (A. sativum L.), and shallot (A. cepa var. aggregatum) (8). Strains from Hawaii, however, induced a hypersensitive response in snap bean (2). X. campestris pv. allii is nonpathogenic to chive and Chinese chive (A. tuberosum Rottler) (16).

The diversity among strains of Xanthomonas strains causing disease on onion is unknown, as is their relationship to other species and pathovars of Xanthomonas. Therefore, this study was initiated to characterize a broad collection of onion Xanthomonas strains from multiple geographic locations over many years by a polyphasic approach. A preliminary report of this work has been presented (12).

\section{MATERIALS AND METHODS}

Bacterial strains, culture, and DNA isolation. Forty-nine strains of Xanthomonas originally isolated from A. cepa or A. fistulosum were obtained from California, Texas, Colorado, Georgia, Hawaii, Brazil, Venezuela, Barbados, South Africa, and Japan, including the type strain of $X$. campestris pv. allii (MAFF 311173) (Table 1). Spontaneous rifampicin and streptomycin mutants of onion Xanthomonas strain O177 (ATCC 508) and X. axonopodis pv. phaseoli strain B458, respectively, were generated as described previously (44) and are referred to as R-O177 and AS-B458, respectively. All antibiotics were purchased from Sigma Chemical (St. Louis). Strain B458 was isolated from dry 
TABLE 1. Xanthomonas and Stenotrophomonas strains used in this study

\begin{tabular}{|c|c|c|c|c|c|c|c|c|}
\hline \multirow[b]{2}{*}{ Strain } & \multirow{2}{*}{$\begin{array}{l}\text { Other strain } \\
\text { designations }\end{array}$} & \multicolumn{3}{|c|}{ Origin } & \multirow[b]{2}{*}{ Source $^{\mathrm{a}}$} & \multirow[b]{2}{*}{ ITS $^{b}$} & \multirow[b]{2}{*}{ RFLP $^{b}$} & \multirow[b]{2}{*}{ hrp $B 6^{\mathrm{b}}$} \\
\hline & & Host & Location & Year & & & & \\
\hline A94-1b & $\ldots$ & Allium cepa & Hawaii & 1977 & A. Alvarez & $\ldots$ & $\ldots$ & $\ldots$ \\
\hline A118-2a & $\ldots$ & Allium cepa & Hawaii & 1977 & A. Alvarez & $\ldots$ & $\ldots$ & $\ldots$ \\
\hline A206-2a & $\ldots$ & Allium cepa & Hawaii & 1977 & A. Alvarez & $\ldots$ & $\ldots$ & + \\
\hline A206-2b & $\ldots$ & Allium cepa & Hawaii & 1977 & A. Alvarez & + & $\ldots$ & + \\
\hline A206-5 & $\ldots$ & Allium cepa & Hawaii & 1977 & A. Alvarez & $\ldots$ & $\ldots$ & $\ldots$ \\
\hline A225-2 & $\ldots$ & Allium сера & Hawaii & 1977 & A. Alvarez & $\ldots$ & $\ldots$ & $\ldots$ \\
\hline A227-2 & $\ldots$ & Allium сера & Hawaii & 1977 & A. Alvarez & $\ldots$ & $\ldots$ & $\ldots$ \\
\hline A229-1 & $\ldots$ & Allium cepa & Hawaii & 1977 & A. Alvarez & + & + & + \\
\hline A255-4 & $\ldots$ & Allium cepa & Hawaii & 1977 & A. Alvarez & $\ldots$ & $\ldots$ & $\ldots$ \\
\hline A256-3 & $\ldots$ & Allium cepa & Hawaii & 1977 & A. Alvarez & $\ldots$ & $\ldots$ & $\ldots$ \\
\hline A274-3 & $\ldots$ & Allium cepa & Hawaii & 1977 & A. Alvarez & $\ldots$ & $\ldots$ & $\ldots$ \\
\hline A274-7a & $\ldots$ & Allium cepa & Hawaii & 1977 & A. Alvarez & $\ldots$ & $\ldots$ & + \\
\hline A551-3 & $\ldots$ & Allium cepa & Hawaii & 1980 & A. Alvarez & $\ldots$ & $\ldots$ & $\ldots$ \\
\hline A554-3 & $\ldots$ & Allium cepa & Hawaii & 1980 & A. Alvarez & $\ldots$ & $\ldots$ & $\ldots$ \\
\hline A579-7 & $\ldots$ & Allium cepa & Hawaii & 1980 & A. Alvarez & $\ldots$ & $\ldots$ & $\ldots$ \\
\hline A1889 & $\ldots$ & Allium cepa & Hawaii & 1987 & A. Alvarez & $\ldots$ & $\ldots$ & $\ldots$ \\
\hline A1890 & $\ldots$ & Allium cepa & Hawaii & 1987 & A. Alvarez & $\ldots$ & $\ldots$ & $\ldots$ \\
\hline JV 594 & CFBP 6362 & Allium сера & Brazil & 1987 & O. Pruvost & + & $\ldots$ & + \\
\hline JV 595 & CFBP 6363 & Allium cepa & Brazil & 1987 & O. Pruvost & + & $\ldots$ & + \\
\hline ATCC 504 & $\mathrm{O} 130$ & Allium cepa & Colorado & 1996 & H. Schwartz & + & $\ldots$ & + \\
\hline ATCC 505 & $\mathrm{O} 153$ & Allium cepa & Colorado & 1996 & H. Schwartz & $\ldots$ & $\ldots$ & + \\
\hline ATCC 506 & $\mathrm{O} 154$ & Allium сера & Colorado & 1996 & H. Schwartz & + & + & + \\
\hline ATCC 507 & $\mathrm{O} 155$ & Allium cepa & Colorado & 1996 & H. Schwartz & + & $\ldots$ & + \\
\hline ATCC 508 & $\mathrm{O} 177$ & Allium cepa & Colorado & 1998 & H. Schwartz & + & $\ldots$ & + \\
\hline B458 & $\ldots$ & Phaseolus vulgaris & Colorado & 2000 & H. Schwartz & + & + & + \\
\hline $\mathrm{F} 2: 22$ & $\ldots$ & Allium cepa & Barbados & 1996 & L. O'Garro & + & $\ldots$ & + \\
\hline JX 721 & CFBP 6387 & Allium cepa & Venezuela & 1997 & O. Pruvost & + & $\ldots$ & $\ldots$ \\
\hline JX 727 & CFBP 6388 & Allium cepa & Venezuela & 2001 & O. Pruvost & + & $\ldots$ & + \\
\hline TX-1a & $\ldots$ & Allium cepa & Texas & 1998 & T. Isakeit & $\ldots$ & $\ldots$ & $\ldots$ \\
\hline $\mathrm{TX}-2 \mathrm{~b}$ & $\ldots$ & Allium cepa & Texas & 1998 & T. Isakeit & + & + & $\ldots$ \\
\hline $\mathrm{TX}-2 \mathrm{c}$ & $\ldots$ & Allium cepa & Texas & 1998 & T. Isakeit & $\ldots$ & $\ldots$ & $\ldots$ \\
\hline TX-3 & $\ldots$ & Allium cepa & Texas & 1998 & T. Isakeit & + & $\ldots$ & + \\
\hline TX-10 & $\ldots$ & Allium cepa & Texas & 1998 & T. Isakeit & + & $\ldots$ & + \\
\hline MAFF 311173 & $\ldots$ & Allium fistulosum & Japan & 1998 & MAFF & + & $\ldots$ & + \\
\hline MAFF 311174 & $\ldots$ & Allium fistulosum & Japan & 1998 & MAFF & + & $\ldots$ & + \\
\hline MAFF 311175 & $\ldots$ & Allium fistulosum & Japan & 1998 & MAFF & $\ldots$ & $\ldots$ & + \\
\hline MAFF 311176 & $\ldots$ & Allium fistulosum & Japan & 1998 & MAFF & $\ldots$ & $\ldots$ & + \\
\hline MAFF 311177 & $\ldots$ & Allium fistulosum & Japan & 1998 & MAFF & $\ldots$ & + & $\ldots$ \\
\hline MAFF 311178 & $\ldots$ & Allium fistulosum & Japan & 1998 & MAFF & + & $\ldots$ & $\ldots$ \\
\hline MAFF 311179 & $\ldots$ & Allium fistulosum & Japan & 1998 & MAFF & $\ldots$ & $\ldots$ & $\ldots$ \\
\hline ATCC BAA 575 & BD 142 & Allium cepa & South Africa & 1999 & ARC-PPRI & + & $\ldots$ & + \\
\hline ATCC BAA 576 & BD 143 & Allium cepa & South Africa & 1999 & ARC-PPRI & + & $\ldots$ & + \\
\hline ATCC BAA 577 & BD 211 & Allium cepa & South Africa & 1999 & ARC-PPRI & $\ldots$ & $\ldots$ & $\ldots$ \\
\hline Xcu 200-2 & $\ldots$ & Allium cepa & Georgia & 2000 & R. Gitaitis & $\ldots$ & $\ldots$ & $\ldots$ \\
\hline Xcu 01-1 & $\ldots$ & Allium cepa & Georgia & 2001 & R. Gitaitis & + & $\ldots$ & + \\
\hline Xcu 01-2 & $\ldots$ & Allium cepa & Georgia & 2001 & R. Gitaitis & + & $\ldots$ & + \\
\hline Calandri-1 & $\cdots$ & Allium cepa & California & 2002 & R. Gilbertson & + & $\ldots$ & $\ldots$ \\
\hline Calandri-3 & $\ldots$ & Allium cepa & California & 2002 & R. Gilbertson & $\ldots$ & $\ldots$ & $\ldots$ \\
\hline Calon-1 & $\ldots$ & Allium cepa & California & 2002 & R. Gilbertson & + & + & $\ldots$ \\
\hline Calon-5 & $\ldots$ & Allium cepa & California & 2002 & R. Gilbertson & + & $\ldots$ & + \\
\hline ATCC 10547 & $\ldots$ & Dacus carota & USA & $\ldots$ & ATCC & $\ldots$ & $\ldots$ & $\ldots$ \\
\hline ATCC 11633 & $\ldots$ & Capsicum annuиm & USA & $\ldots$ & ATCC & $\ldots$ & $\ldots$ & $\ldots$ \\
\hline ATCC 11672 & $\ldots$ & Xanthium strumarium & India & 1950 & ATCC & $\ldots$ & $\ldots$ & $\ldots$ \\
\hline ATCC 11765 & $\ldots$ & Medicago sativa & India & $\ldots$ & ATCC & $\ldots$ & $\ldots$ & $\ldots$ \\
\hline ATCC 13461 & $\ldots$ & Holcus sp. & Texas & 1978 & ATCC & $\ldots$ & $\ldots$ & $\ldots$ \\
\hline ATCC 13637 & $\ldots$ & Homo sapiens & $\ldots$ & 1960 & ATCC & $\ldots$ & $\ldots$ & $\ldots$ \\
\hline ATCC 19047 & $\ldots$ & Piper betle & India & 1964 & ATCC & $\ldots$ & $\ldots$ & $\ldots$ \\
\hline ATCC 19312 & $\ldots$ & Axопори scoparius & Columbia & $\ldots$ & ATCC & $\ldots$ & $\ldots$ & $\ldots$ \\
\hline ATCC 19313 & $\ldots$ & Corylus maxima & Oregon & $\ldots$ & ATCC & $\ldots$ & $\ldots$ & $\ldots$ \\
\hline ATCC 29088 & $\ldots$ & Lolium multiflorium & Switzerland & 1975 & ATCC & $\ldots$ & $\ldots$ & $\ldots$ \\
\hline ATCC 29091 & $\ldots$ & Dactylis glomerata & Switzerland & 1975 & ATCC & $\ldots$ & $\ldots$ & $\ldots$ \\
\hline ATCC 33913 & $\ldots$ & Brassica oleracea & UK & $\ldots$ & ATCC & $\ldots$ & $\ldots$ & $\ldots$ \\
\hline ATCC 35937 & $\cdots$ & Lycopersicon lycopersicum & New Zealand & $\cdots$ & ATCC & $\ldots$ & $\cdots$ & $\cdots$ \\
\hline ATCC 49079 & $\ldots$ & Raphunus sativus & USA & $\ldots$ & ATCC & $\ldots$ & $\ldots$ & $\ldots$ \\
\hline ATCC 49083 & $\ldots$ & Juglans regia & New Zealand & $\ldots$ & ATCC & $\ldots$ & $\ldots$ & $\ldots$ \\
\hline ATCC 49119 & $\ldots$ & Phaseolus vulgaris & USA & 1989 & ATCC & $\ldots$ & $\ldots$ & $\ldots$ \\
\hline ATCC 49120 & $\ldots$ & Citrus sp. & Florida & 1989 & ATCC & $\ldots$ & $\ldots$ & $\ldots$ \\
\hline
\end{tabular}

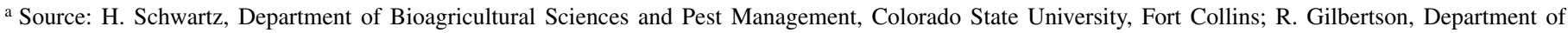
Plant Pathology, University of California, Davis; T. Isakeit, Department of Plant Pathology and Microbiology, Texas A\&M University, College Station; MAFF = Ministry of Agriculture, Forestry, and Fisheries of Japan, Okinawa; ATCC = American Type Culture Collection, Manassas, VA; L. O'Garro, Department of Biology, University of the West Indies, Bridgetown, Barbados; A. Alvarez, Department of Plant Pathology, University of Hawaii, Honolulu; R. Gitaitis, Department of Plant Pathology, University of Georgia, Tifton; ARC-PPRI = Agricultural Research Council-Plant Protection Research Institute, Pretoria, South Africa; O. Pruvost, Centre de Coopération Internationale en Recherche Agronomique pour le Dévelopement, Reunion Island, France.

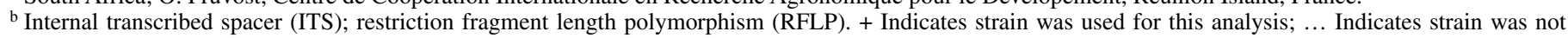
used for this analysis. 
bean pinto cv. Bill Z in southwestern Colorado. Strain R-O177 and AS-B458 are resistant to greater than $200 \mu \mathrm{g}$ of rifampicin or streptomycin per $\mathrm{ml}$, respectively, but selection routinely was performed on nutrient agar amended with $50 \mu \mathrm{g}$ of the appropriate antibiotic per $\mathrm{ml}$. Other strains were routinely cultured on nutrient agar or broth lacking antibiotic during incubation at $26^{\circ} \mathrm{C}$, and bacterial strains were preserved in $15 \%$ nutrient glycerol broth at $-80^{\circ} \mathrm{C}$ for long-term storage.

Strains were cultured in $1.5 \mathrm{ml}$ of nutrient broth for $24 \mathrm{~h}$ for DNA isolation procedures. The culture was adjusted to an optical density of 0.1 at $600 \mathrm{~nm}$ in sterile $0.02 \mathrm{M}$ potassium phosphate buffer (PB), pH 7.2, and DNA was isolated with the CTAB (hexadecyltrimethylammonium bromide) method (4). DNA was stored in Tris-EDTA (TE) buffer $(10 \mathrm{mM}$ Tris and $1 \mathrm{mM}$ EDTA, $\mathrm{pH} 8.0)$ at $-20^{\circ} \mathrm{C}$.

Pathogenicity and host range. All strains were tested for pathogenicity on A. cepa (cv. Blanco Duro) in growth chamber assays. Pathogenicity on A. fistulosum (cv. White Welsh) was confirmed with representative strains from nine geographical regions, including O177, Calon-1, TX-3, ATCC BAA 576, Xcu 01-1, MAFF 311173, A229-1, JV 594, and JX 727. Colonies of the strain to be tested were inoculated into $3 \mathrm{ml}$ of nutrient broth in $15-\mathrm{ml}$ culture tubes and were incubated at $26^{\circ} \mathrm{C}$ with vigorous shaking ( 250 oscillations per $\min$ ) for $24 \mathrm{~h}$. The cultures were adjusted to approximately $10^{7} \mathrm{CFU} / \mathrm{ml}$ in sterile PB before spraying (Crown SpraTool, Aerovoe Industries, Inc., Gardnerville, NV) the foliage of 6- to 8-week-old plants to runoff with the bacterial suspension. Control plants were inoculated with sterile PB. The plants were placed in a growth chamber and incubated for 7 days with a $28^{\circ} \mathrm{C} / 24^{\circ} \mathrm{C}$ day/night temperature regime, light intensity of $350 \mu \mathrm{Ms}^{-1} \mathrm{~m}^{-2}, 100 \%$ relative humidity, and daily misting with tap water to runoff. At least four plants were inoculated with each strain. Plants were observed daily for symptom development, and the pathogen was isolated from characteristic lesions by grinding leaf sections in $1 \mathrm{ml}$ of PB with a sterile mortar and pestle and streaking loopfuls of the homogenate onto nutrient agar. The pathogen was confirmed as Xanthomonas by carbon and nitrogen substrate utilization patterns on Biolog GN Microplates (Biolog, Inc., Hayward, CA) as described previously (43).

Pathogenicity on dry bean (cv. Sacramento Light Red Kidney) was also evaluated by the spray inoculation method described for onion, except plants were kept in the growth chamber for 14 days. All plants were 4 to 5 weeks old when inoculated.

Multiplication of the rifampicin resistant onion strain R-O177 and streptomycin resistant bean strain AS-B458 in inoculated dry bean, pepper (Capsicum annuum L., cv. Sweet California Wonder), and onion were quantified as described previously (27). Briefly, a single colony of each pathogen was picked from a 72-h nutrient agar plate and grown overnight in nutrient broth $\left(26^{\circ} \mathrm{C}\right.$ and 250 oscillations per min) to the mid-logarithmic phase. The culture was adjusted to approximately $10^{8} \mathrm{CFU} / \mathrm{ml}$ spectrophotometrically $\left(A_{600}=0.12\right)$ with sterile $\mathrm{PB}$, diluted to $10^{4} \mathrm{CFU} / \mathrm{ml}$ in sterile $\mathrm{PB}$, and pressure infiltrated into the youngest, fully expanded bean and pepper leaflets of 4- to 5-week-old plants with a sterile $1-\mathrm{ml}$ syringe. Trace levels of nutrient broth $(1 \mu \mathrm{l}$ or less per $10 \mathrm{ml}$ of sterile $\mathrm{PB}$ ) from the cultivation media were also introduced into the plant during inoculation but were assumed not to contribute to bacterial replication in planta. Five $20-\mathrm{mm}^{2}$ leaf disks were immediately removed (each from a different leaflet) with an ethanol-sterilized cork borer and surface-disinfested in 95\% ethanol followed by several rinses in sterile PB before grinding individually in $100 \mu \mathrm{l}$ of PB with a sterile mortar and pestle. The homogenate was serially diluted in sterile PB, and 100- $\mu$ l droplets were plated in duplicate onto nutrient agar with the appropriate selection antibiotic. Plants serving as controls were infiltrated with sterile $\mathrm{PB}$, and the homogenate was plated onto nutrient agar. Leaf disks were removed daily for 7 days to generate population growth curves.
Populations in onion were determined as described by O'Garro and Paulraj (27). Briefly, the youngest, fully extended leaves of 8 -week-old onion plants (cv. Blanco Duro) were pinpricked seven times at $1-\mathrm{cm}$ intervals with a 22 -gauge needle bearing strain RO177 or AS-B458 removed from 72-h-old nutrient agar culture plates. Each pinpricked leaf area was inoculated with a bacterial matrix approximately equal in size to the needle tip. Leaf sections ( 5 by $1 \mathrm{~cm}$ in length), each having an inoculated area, were removed every 2 days, surface-disinfested in $95 \%$ ethanol, rinsed in sterile $\mathrm{PB}$, and ground aseptically in $1 \mathrm{ml}$ of sterile $\mathrm{PB}$ with a mortar and pestle. Recoveries were done up to 14 days after inoculation to generate population growth curves. The homogenate was serially diluted and plated onto nutrient agar amended with $50 \mu \mathrm{g}$ of the appropriate selection antibiotic per $\mathrm{ml}$. Colonies were enumerated after $72 \mathrm{~h}$ of incubation at $26^{\circ} \mathrm{C}$, and characteristic colonies were confirmed as strain R-O177 or AS-B458 by genomic fingerprinting with BOX primers as described previously (20). Pathogenicity of recovered onion Xanthomonas strain R-O177 and X. axonopodis pv. phaseoli strain AS-B458 on onion cv. Blanco Duro and dry bean cv. Sacramento Light Red Kidney, respectively, was conducted as described previously.

Copper, zinc, and streptomycin resistance screening. The minimum inhibitory concentrations (MIC) of $\mathrm{CuSO}_{4}, \mathrm{ZnSO}_{4}$, and streptomycin sulfate were determined using a modification of the broth microdilution test guidelines from the National Committee for Clinical Laboratory Standards (25). Serial dilutions (1:2) of each bactericide were made in nutrient broth in round-bottom 96well plates to a final volume of $100 \mu \mathrm{l}$ per well. Each well was inoculated with $5 \mu \mathrm{l}$ of a $10^{7} \mathrm{CFU} / \mathrm{ml}$ suspension of Xanthomonas sp. from a $3-\mathrm{ml}$ nutrient broth overnight culture. The MIC was considered the lowest concentration of each bactericide that completely inhibited visual growth after $24 \mathrm{~h}$. Xanthomonads are generally considered resistant to copper, zinc, or streptomycin if they are able to grow on artificial media amended with 100 to $200 \mu \mathrm{g}$ of a given bactericide per $\mathrm{ml}(6,7,17,24,39)$. In this study, strains were considered resistant to $\mathrm{CuSO}_{4}, \mathrm{ZnSO}_{4}$, or streptomycin sulfate if the MIC was greater than $100 \mu \mathrm{g} / \mathrm{ml}$. X. axonopodis pv. vesicatoria strains 81-23 and E3 (provided by J. Jones, University of Florida) were included as copper and streptomycin resistant positive controls, respectively.

Substrate utilization and fatty acid methyl ester profiles. Substrate utilization and fatty acid methyl ester profiles were generated for all 49 onion Xanthomonas strains presented in Table 1 by Microbe Inotech Laboratories, Inc. (St. Louis) by standard procedures $(42,43)$. Cultures were streaked onto trypticase soy broth agar at $26^{\circ} \mathrm{C}$ for $24 \mathrm{~h}$ before inoculating onto Biolog GN microplates according to Biolog protocols for gram-negative aerobic bacteria. The resulting metabolic fingerprints were read by an automated plate reader and compared with version 4.1 of the Biolog database. Fatty acid compositions were determined by gas chromatographic analysis by standard methods and compared with the Microbial Identification Aerobe (version 4.1) and Clinical Aerobe (version 4.0) databases (MIDI, Newark, DE).

hrp B6 gene amplification and sequencing. A portion of the highly conserved putative ATPase gene hrp B6 was amplified from extracted genomic DNA with oligonucleotide primers RST2 (5'-AGGCCCTGGAAGGTGCCCTGGA-3') and RST3 (5'-ATCGCACTGCGTACCGCGCGCGA-3'), which direct the amplification of an approximately 840-bp fragment $(11,18)$. DNA was extracted from 24 strains (Table 1) as described previously; one to five representative strains from each geographic location were selected for the experiment. A polymerase chain reaction (PCR) product for this gene is expected from most phytopathogenic xanthomonads, but is not expected from nonpathogenic xanthomonads that lack the hrp gene cluster. DNA was amplified in reaction mixtures containing $12.5 \mu \mathrm{l}$ of PCR Master Mix (Promega, Madison, WI), $1 \mu \mathrm{M}$ each primer, $100 \mathrm{ng}$ of CTAB extracted DNA, and PCR-grade water to a total volume of $25 \mu \mathrm{l}$. PCR 
amplification cycle conditions were as described by Leite et al. (18). Amplified DNAs were separated by electrophoresis in $1.0 \%$ agarose (Bio-Rad Laboratories, Hercules, CA) gels in Tris-acetate buffer (40 mM Tris-acetate and $1 \mathrm{mM}$ EDTA, pH 8.2). Ethidium bromide $(0.5 \mu \mathrm{g} / \mathrm{ml})$ was added to each gel, and the DNA fragments were visualized over a UV transilluminator (Fotodyne, Hartland, WI). The approximate 840-bp amplicon was gel purified (Qiagen MinElute Gel Extraction Kit, Qiagen, Inc., Valencia, CA) and sequenced (Davis Sequencing, Davis, CA). Sequence, alignment, calculation of similarity values, and cluster analysis were performed with MegAlign software (DNASTAR, Inc., Madison, WI). The National Center for Biotechnology Information GenBank nonredundant database was searched for sequence similarity using the BLASTn algorithm (1).

$16 \mathrm{~S}$ and intergenic spacer region restriction fragment length polymorphism and sequencing. PCR experiments were performed as described previously (22) to amplify the entire $16 \mathrm{~S}$ and 16S-23S rDNA internally transcribed spacer (ITS) region or only the $16 \mathrm{~S}-23 \mathrm{~S}$ rDNA ITS region using universal primer pairs 27F (5'-AGAGTTTGATCCTGGCTCAG-3')/FGPS-132 (5'-CCGGGTTTCCCCATTCGG-3') or G1 (5'-GAAGTCGTAACAAGG-3')/L1 (5'-CAAGGCATCCACCGT-3'), respectively. Oligonucleotide primers were synthesized by Integrated DNA Technologies (Coralville, IA). One to five representative strains from each geographic location were used in each experiment. A 10- $\mu$ l aliquot of the resulting DNA fragment from the $16 \mathrm{~S}$ and ITS region amplified by primers $27 \mathrm{~F}$ and FGPS-132 was restricted with EcoRI or HaeIII as recommended by the manufacturer (Promega) and separated by electrophoresis in $1.0 \%$ agarose (Bio-Rad Laboratories) gels, visualized, and photographed as described previously. The ITS amplicon was gel purified (Qiagen) and sequenced (Davis Sequencing). Sequence alignment, calculation of similarity values, and cluster analysis were performed with MegAlign software. The National Center for Biotechnology Information GenBank nonredundant database was searched for sequence similarity using the BLASTn algorithm (1).

Repetitive sequence based-PCR genomic fingerprinting. Genomic fingerprints were determined for each strain as described by Louws et al. (19-21) using primers corresponding to prokaryotic enterobacterial repetitive intergenic consensus (ERIC) sequences, repetitive extragenic palindromic (REP) sequences, and the BOXA subunit of the BOX element. Stenotrophomonas maltophilia was included as a positive control. Additionally, 45 other strains of phytopathogenic xanthomonads representative of the DNA:DNA homology groups described by Vauterin et al. (41) were included to determine the relationship of onion strains of Xanthomonas to other species and pathovars of Xanthomonas. Seventeen of these strains are included in this report (Table 1).

Images were imported into GelCompar software (version 4.1, Applied Maths, Kortrijk, Belgium) and linearly combined, and similarity was calculated using Pearson's correlation coefficient applied to the entire densitometric curves of the gel tracks as described previously (31). Gels were standardized with a 1-kb DNA molecular weight ladder (Invitrogen Corp., Carlsbad, CA). Cluster analysis was performed by the unweighted pair group method with arithmetic averages clustering. All PCR reactions were repeated at least twice.

Statistical analysis. Analysis of in planta population growth was conducted with SAS version 8.0 (PROC MIXED, SAS Institute, Cary, NC) to generate means and standard errors of logtransformed data. Factor analysis was conducted on merged Bio$\log$ and fatty acid profile data sets to generate 10 unique and uncorrelated factors (SAS PROC FACTOR) with orthogonal varimax rotation. These factors were subsequently used in logistic regression (PROC LOGISTIC) with stepwise selection to predict the region of origin of each strain. Cluster and principal component analysis of fatty acid composition content and substrate utilization profiles were conducted with MINITAB 13 (Minitab, Inc., State College, PA) using the unweighted pair group method with arithmetic averages clustering. The percent color change in each Biolog GN2 MicroPlate well, compared with the water control, was used in cluster and principal component analysis. Percent compositions of each fatty acid were used in the analysis of fatty acid profiles.

\section{RESULTS}

Pathogenicity and host range. All onion strains of Xanthomonas used in this study were pathogenic on onion except strains

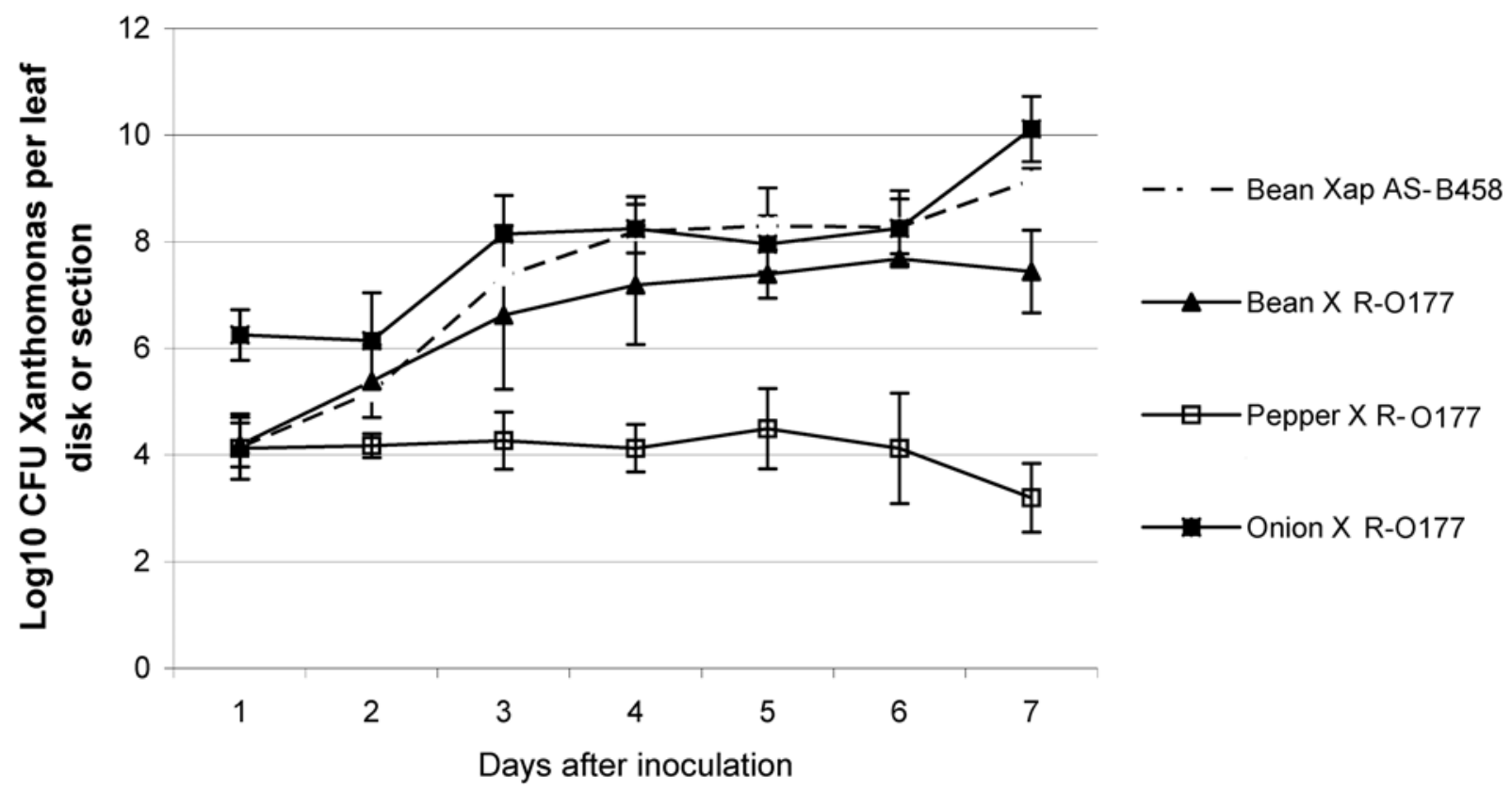

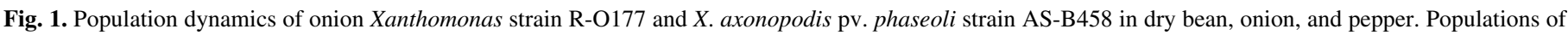

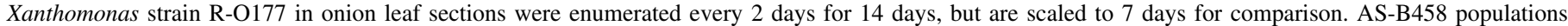

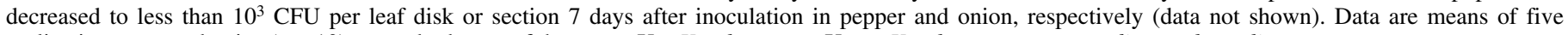
replications repeated twice $(n=10) \pm$ standard error of the mean. $\mathrm{X}=$ Xanthomonas; Xap $=$ Xanthomonas axonopodis pv. phaseoli. 
A1889, A1890, and TX-2b. Strain TX-2b was identified as $X$. campestris pv. carotae by repetitive sequence-based (rep)-PCR, Biolog, and ITS sequence and produced typical bacterial leaf blight symptoms on carrot (Daucus carota L.). Characteristic lenticular-shaped, water-soaked lesions also developed on $A$. fistulosum within 7 days following inoculation with representative strains from nine geographical regions. Disease symptoms were not observed with any onion strain of Xanthomonas on dry bean cv. Sacramento Light Red Kidney, but typical common bacterial blight symptoms were observed on dry bean 5 days after inoculating with $X$. axonopodis pv. phaseoli strain AS-B458.

Populations of onion Xanthomonas strain R-O177 increased in planta in dry bean and onion, but not in pepper (Fig. 1). Populations of $X$. axonopodis pv. phaseoli strain AS-B458 and onion Xanthomonas strain R-O177 increased in dry bean to greater than $10^{8}$ and $10^{7} \mathrm{CFU}$ per $20-\mathrm{mm}^{2}$ leaf disk, respectively, 7 days after

\section{Euclidean Distance}

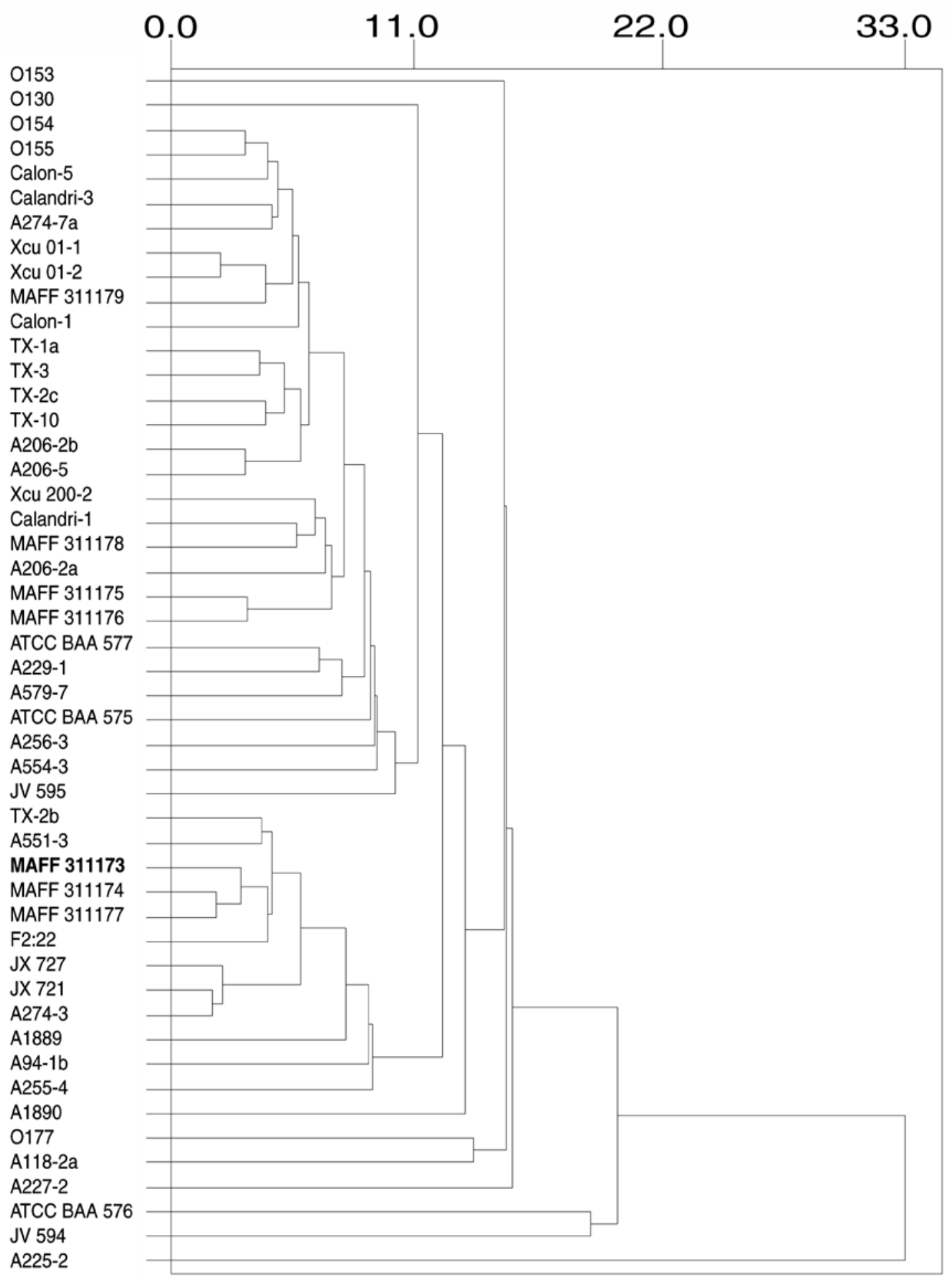

Fig. 2. Relationships among 49 onion Xanthomonas strains isolated from various geographical regions based on Biolog GN Microplate (Biolog, Inc., Hayward, CA) substrate utilization patterns. The type strain of X. campestris pv. allii MAFF 311173 is noted in bold. 
inoculation. Strain R-O177 increased to greater than $10^{8} \mathrm{CFU}$ per $1-\mathrm{cm}$ leaf section in onion during the study time course. Populations of $X$. axonopodis pv. phaseoli decreased to less than $10^{3} \mathrm{CFU}$ per sample area in onion and pepper 7 days after inoculation (data not shown).

Copper, zinc, and streptomycin resistance screening. Resistance to copper, zinc, or streptomycin was not observed among onion strains of Xanthomonas; all were inhibited by $100 \mu \mathrm{g} / \mathrm{ml}$ or less of copper sulfate, zinc sulfate, or streptomycin. All strains were highly sensitive to streptomycin and were inhibited by $1.6 \mu \mathrm{g} / \mathrm{ml}$ or less.

Substrate utilization and fatty acid methyl ester profiles. A diversity of substrate utilization and fatty acid methyl ester profiles was observed in onion strains of Xanthomonas. Mean Biolog and fatty acid profile similarity indices of the 49 onion Xanthomonas strains tested were 0.62 and 0.78 , respectively, with the $X$. axonopodis profile. Corresponding distance coefficients for Biolog and fatty acid profiles were 4.428 and 2.581 , respectively, compared with the $X$. axonopodis profile. The closest pathovar matches within the Biolog database were $X$. axonopodis pv. dieffenbachiae (57\%), X. axonopodis pv. begonia (16\%), X. axonopodis pv. phaseoli (4\%), and $X$. axonopodis pv. malvacearum (4\%). Nearly $12 \%$ of the strains did not have a closest match and were simply identified as X. axonopodis. The MIDI Aerobe and Clinical Aerobe fatty acid databases indicated that onion strains of Xanthomonas were most closely related to $X$. arboricola pv. poinsettiicola (37\%), X. axonopodis pv. dieffenbachiae (18\%), and $X$. axonopodis pv. citrumelo $(16 \%)$.

Biolog substrate utilization profiles revealed diversity in carbon and nitrogen utilization patterns by onion strains of Xanthomonas, but this diversity was not fully explained by geographic origin (Fig. 2). Euclidean distances among strains were less than 13 with the exception of strains JV 594 (Brazil), ATCC BAA 576 (South Africa), and A225-2 (Hawaii). Principal component analysis did not reveal distinct clustering of strains (data not shown).

Onion strains of Xanthomonas contained high proportions of

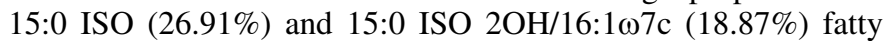
acids. The 10:0, 10:0 2OH, 11:0 3OH, 12:0, 13:0 ISO, 13:0 2OH, 17:1 $\omega 6 \mathrm{c}, 17: 1$ 10methyl, and 17:0 ISO $3 \mathrm{OH}$ fatty acids comprised less than $1.22 \%$ of the total fatty acid profile or were absent in all strains. Table 2 presents fatty acid composition profiles for five representative strains that characterize the diversity of fatty acid profiles in the 49 onion strains of Xanthomonas included in this study. Cluster analysis of fatty acid profiles revealed phenotypic diversity in onion strains of Xanthomonas that was partially explained by geographic origin (Fig. 3). Euclidean distances among strains were generally less than 5, except for six strains from Hawaii and strains O177, TX-2b, Xcu 01-1, and F2:22, suggesting little diversity in fatty acid composition. Strains from California formed a distinct group that also included Georgia strain Xcu 200-2. Japanese strains formed two distinct but highly related subgroups (Euclidean distance less than 4 ), but other strains were not grouped solely by geographic origin. Strains A1889 and A1890, which were not pathogenic to onion, had a nearly identical fatty acid profile but were dissimilar from all other evaluated strains. Additionally, principal component analysis did not reveal distinct clustering of strains (data not shown). Several fatty acids were only occasionally recovered from strains or were present at low levels and may have obscured the variability among geographical regions, reducing the power of principal component analysis to separate strains by geography. Fatty acid methyl ester profiles alone were not useful for determining geographic origin of all strains.

Factor analysis of combined Biolog substrate utilization and fatty acid profile data and subsequent logistic regression yielded a model with two factors (Factors 1 and 9) that correctly placed $69.3 \%$ of strains into their geographical region; $23.5 \%$ were misclassified and $7.2 \%$ were tied. The likelihood equations for each equation were computed as $Z=\beta_{0}+0.782$ (Factor 1$)+$ 0.865 (Factor 2), where $\beta_{0}$ is the cumulative logit intercept for each region given in Table 3 . The probability of group membership of a strain in a region $\left(Z_{i}\right)$ is described by $p\left(R_{i}\right)=e^{Z i} /\left(1+e^{Z i}\right)$, where $e$ is the natural logarithm. The probability of group membership in Venezuela is given by $p\left(R_{\text {Venezuela }}\right)=1-p\left(R_{\text {Texas }}\right)$.

hrp $B 6$ gene amplification and sequencing. A single DNA fragment was amplified with all onion Xanthomonas strains examined in this study. Sequence similarity of 97 to $98 \%$ was observed with onion Xanthomonas strains compared with the partial hrp gene sequence of $X$. axonopodis pv. vesicatoria (Accession No. U33548), which was previously deposited in GenBank (10). Cluster analysis revealed five distinct groups that generally grouped by geographical region of origin (data not shown). Strains from Texas, South Africa, and Colorado did not group solely by geographical region of origin.

$16 S$ and ITS region restriction fragment length polymorphism and sequencing. All onion strains of Xanthomonas

TABLE 2. Cellular fatty acid composition of five representative onion strains of Xanthomonas sp. from different geographical regions and belonging to five repetitive sequence based-polymerase chain reaction (rep-PCR) genotype groups

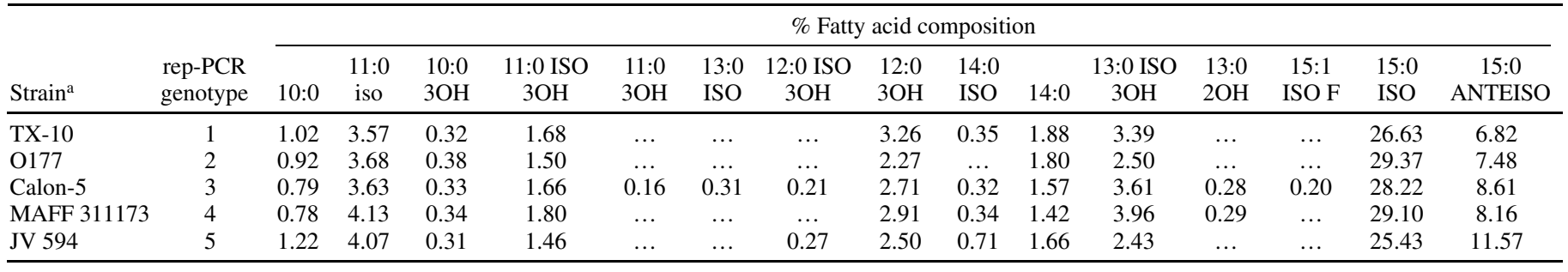

$\%$ Fatty acid composition

\begin{tabular}{|c|c|c|c|c|c|c|c|c|c|c|c|c|c|c|c|}
\hline \multirow[b]{2}{*}{ Strain } & \multirow[b]{2}{*}{$\begin{array}{l}\text { rep-PCR } \\
\text { genotype }\end{array}$} & \\
\hline & & $\begin{array}{l}15: 1 \\
\omega 6 \mathrm{c}\end{array}$ & $15: 0$ & $\begin{array}{l}16: 0 \\
\text { ISO }\end{array}$ & $\begin{array}{l}16: 1 \\
\omega 9 \mathrm{c}\end{array}$ & $16: 0$ & $\begin{array}{c}\text { ISO } \\
17: 1 \omega 9 \mathrm{c}\end{array}$ & $\begin{array}{l}17: 0 \\
\text { ISO }\end{array}$ & $\begin{array}{c}17: 0 \\
\text { ANTEISO }\end{array}$ & $\begin{array}{l}17: 1 \\
\omega 8 \mathrm{c}\end{array}$ & $\begin{array}{l}18: 1 \\
\omega 9 \mathrm{c}\end{array}$ & $\begin{array}{l}18: 1 \\
\omega 7 \mathrm{c}\end{array}$ & $\begin{array}{c}\text { 17:0 ISO } \\
3 \mathrm{OH}\end{array}$ & $\begin{array}{c}\text { Sum } \\
\text { F3 }^{\mathrm{b}}\end{array}$ & Unknown \\
\hline TX-10 & 1 & $\ldots$ & 1.52 & 1.86 & 2.16 & 7.19 & 4.86 & 8.36 & 0.52 & 1.02 & 0.77 & 0.91 & $\ldots$ & 20.34 & 1.60 \\
\hline $\mathrm{O} 177$ & 2 & $\ldots$ & 1.74 & 1.56 & 1.76 & 6.99 & 4.94 & 8.02 & 0.51 & 0.96 & 0.69 & $\ldots$ & & 19.98 & 2.96 \\
\hline MAFF 311173 & 4 & 0.28 & 1.33 & 2.04 & 1.55 & 6.17 & 5.28 & 8.07 & 0.62 & 0.95 & 0.55 & 0.59 & $\ldots$ & 18.18 & 1.17 \\
\hline JV 594 & 5 & 0.47 & 1.66 & 3.69 & 1.90 & 5.47 & 4.54 & 6.06 & 0.69 & 1.09 & 0.65 & 0.67 & $\ldots$ & 18.97 & 2.50 \\
\hline
\end{tabular}

${ }^{a}$ Fatty acid composition data for 5 of the 49 onion Xanthomonas strains analyzed that represent the diversity of fatty acid profiles observed among strains pathogenic to onion.

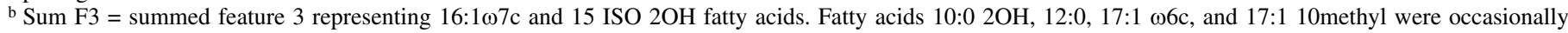
detected in some strains but comprised less than $1 \%$ of the total fatty acid profile. The representative strains presented lacked these four fatty acids and are not shown. 
analyzed contained a single $16 \mathrm{~S}-23 \mathrm{~S}$ ITS region. Sequencing of the PCR amplified ITS region yielded an approximately 600-bp amplicon with greater than $99 \%$ sequence similarity to the ITS region of $X$. axonopodis pv. citrumelo strain F1 (Accession No. AF442741), which was previously deposited in GenBank (9). All strains differed from $X$. axonopodis pv. citrumelo strain $\mathrm{F} 1$ by 5 bp or less except for strains A299-1 (9 bp) and TX-2b (18 bp). The ITS sequence of strain TX-2b was $100 \%$ similar to Accession No. AF279428 from X. campestris pv. carotae (5). Onion strains of Xanthomonas also appear to contain the transfer RNA (tRNA) genes tRNA Ala and tRNA ${ }^{\text {Ile }}$.
Variability within the ITS region was limited among onion strains of Xanthomonas. Greater than $98 \%$ sequence similarity was observed among strains evaluated, but strains from Japan, California, Brazil, Venezuela, Texas, Hawaii, and South Africa generally grouped by geographical region of origin in cluster analysis (data not shown). Strains from Colorado and Georgia did not group by region.

No polymorphisms were detected among onion strains of Xanthomonas evaluated when the entire $16 \mathrm{~S}+$ ITS region was amplified and subsequently restricted with EcoRI or HaeIII. However, $X$. axonopodis pv. phaseoli strain B458 did exhibit a polymorphic

\section{Euclidean Distance}

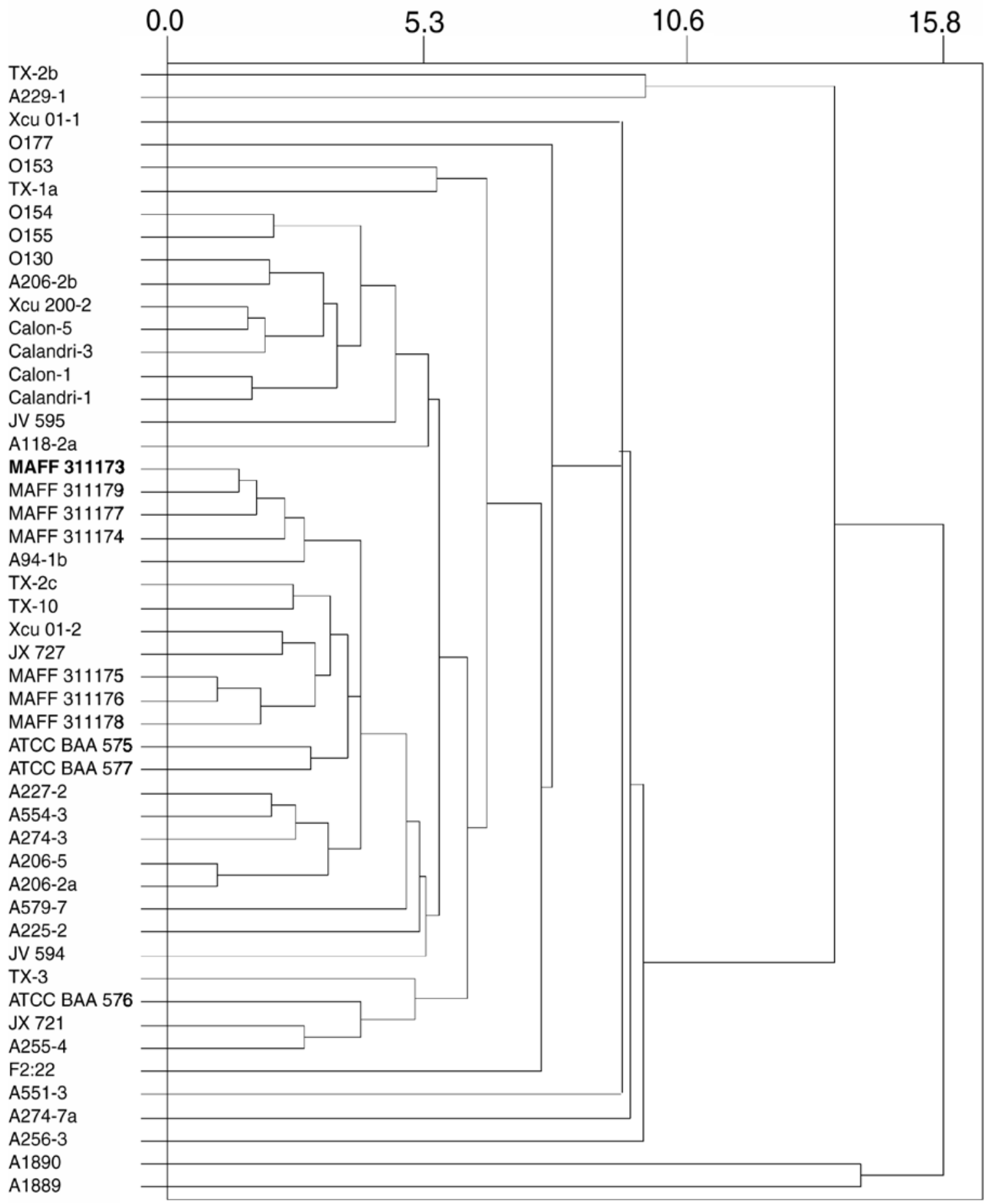

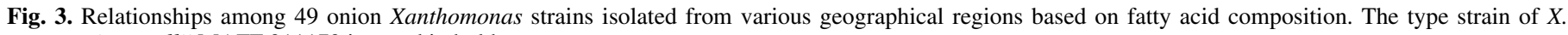
campestris pv. allii MAFF 311173 is noted in bold. 
band, approximately $150 \mathrm{bp}$, compared with onion strains of Xanthomonas when restricted with HaeIII (data not shown), suggesting onion strains of Xanthomonas are genetically distinct from $X$. axonopodis pv. phaseoli.

rep-PCR genomic fingerprinting. Complex DNA fingerprints were generated from genomic DNA extracted from 49 onion Xanthomonas strains, 45 other Xanthomonas species and pathovars, and the Stenotrophomonas maltophilia positive control (Fig. 4). Amplified DNA fragments ranged in size from approximately $200 \mathrm{bp}$ to greater than $4 \mathrm{~kb}$ and revealed a high degree of genetic diversity among onion strains of Xanthomonas. DNA fingerprint similarity among onion Xanthomonas strains ranged from greater than $98 \%$ to less than $50 \%$. Onion Xanthomonas strains formed five distinct genotypes that were largely but not entirely explained by geographical origin. The majority of strains (30\%) belonged to genotype 2, which all originated from Hawaii except for Colorado strain O177. Genotype 4 strains comprised $25 \%$ of the strains analyzed and represented strains originating from California, Georgia, Colorado, and Venezuela. Seven strains originally isolated from A. fistulosum in Japan, including the type strain of $X$. campestris pv. allii, comprised genotype 4. Thirteen percent of the strains comprised the heterogeneous genotype 5 and included strains from Brazil, South Africa, Barbados, and Texas strain TX2c. Genotype 1 comprised three strains $(6 \%)$ from Texas. TX-2b had a nearly identical DNA fingerprint as the $X$. campestris pv. carotae type strain, and produced typical bacterial leaf blight symptoms on carrot, but was not pathogenic to onion. Strains A1890, A1889, and A91-1a did not cluster with the five other onion Xanthomonas genotypes.

Eight rep-PCR DNA fragments were common to the five genotype groups of onion Xanthomonas strains (Fig. 5) and appear to be signature bands of these strains. Strains pathogenic on onion share these DNA fragments, including $X$. campestris pv. allii strains, independent of geographical region of origin. All eight of these bands are present in the $X$. axonopodis pv. citrumelo type strain, but seven bands are also present in $X$. axonopodis pv. alfalfae and $X$. axonopodis pv. betlicola. The DNA fingerprint of $X$. axonopodis pv. citrumelo was nearly identical to Colorado strain $\mathrm{O} 177$ and grouped within genotype 2 (Figs. 4 and 6). The $X$. axonopodis pv. betlicola type strain DNA fingerprint was also highly similar to genotype 2 strains. $X$. axonopodis pv. alfalfae grouped with genotype 4 strains from Japan, and $X$. axonopodis pv. vesicatoria grouped with the heterogeneous genotype 5 strains. The other pathovars of Xanthomonas that grouped with onion Xanthomonas strains all belong to DNA homology group 9-2 (41), providing strong evidence that onion Xanthomonas strains also belong within DNA homology group 9-2.

\section{DISCUSSION}

In this paper, we describe the phenotypic and genetic diversity among strains of Xanthomonas causing Xanthomonas leaf blight of onion and the relationship of these strains to other described Xanthomonas pathovars and species. Of particular importance is the relationship of onion Xanthomonas strains to the described pathovar $X$. campestris pv. allii. We conclude that the onion Xanthomonas strains examined in this study are pathovar $X$. campestris pv. allii based upon pathogenicity to onion, as well as phenotypic (carbon substrate utilization, fatty acid profiles) and genetic ( $h r p$ b6 gene sequence, 16S rDNA restriction fragment length polymorphism [RFLP] profile, ITS sequence, and repPCR-mediated DNA fingerprints) similarities. A pathovar is designated solely based on distinctive pathogenicity to one or more plant hosts (10). The X. campestris pv. allii and onion Xanthomonas strains included in this study were indistinguishable based on pathogenicity to A. cepa and A. fistulosum and, therefore, satisfy the basic requirement for pathovar designation. DNA fingerprinting by rep-PCR demonstrated that although con- siderable genetic diversity is present within onion Xanthomonas strains, the strains included in this study clearly group with and belong to the described pathovar $X$. campestris pv. allii. No onion strains of Xanthomonas, including the type strain of $X$. campestris pv. allii, grouped with the $X$. campestris DNA homology group 15 strains. However, they all grouped within the $X$. axonopodis DNA homology group 9-2, indicating the correct species epithet should be $X$. axonopodis and not $X$. campestris. Therefore, we propose onion strains of Xanthomonas be classified as $X$. axonopodis pv. allii to correctly represent their genotypic and phylogenetic relationship to other $X$. axonopodis species within DNA homology group 9-2. Onion strains of Xanthomonas are hereafter referred to as $X$. axonopodis pv. allii. The results of this polyphasic characterization and transfer of $X$. campestris pv. allii strains to $X$. axonopodis pv. allii are in agreement with similar research independently conducted by Rougmanac et al. (33).

Additionally, the high ITS sequence similarity and 16S RFLP profiles among strains suggest that a close phylogenetic relationship exists within $X$. axonopodis pv. allii. The limited genetic diversity within the $16 \mathrm{~S}$ rDNA region is consistent with other findings (13) and may limit utility of the ITS region for differentiating $X$. axonopodis pv. allii from other xanthomonads. However, the rDNA spacer region is useful for identifying other bacteria (15) and could provide presumptive identification of $X$. axonopodis pv. allii. Describing this relationship among these strains and between other Xanthomonas species and pathovars should clarify the taxonomic position of $X$. axonopodis pv. allii, and elucidation of this relationship should aid in identification and future epidemiological studies of $X$. axonopodis pv. allii.

Pathogenicity on onion and multiplication in dry bean were clearly demonstrated, but the absence of disease symptoms on dry bean suggests that most $X$. axonopodis pv. allii strains may be only weakly virulent on dry bean and perhaps other pulse crops. Alternatively, dry bean may be a nonsymptomatic host of some $X$. axonopodis pv. allii strains. Pathogenicity and/or virulence on alternate hosts (i.e., pulse crops) appears to be highly variable among populations of $X$. axonopodis pv. allii. In this study, bean common bacterial blight disease symptoms were absent in all $X$. axonopodis pv. allii strains evaluated, but the Barbados population is reportedly highly virulent on dry bean and other pulse crops (27). Although most $X$. axonopodis pv. allii strains appear weakly virulent, dry beans may serve as a reservoir of $X$. axono-

TABLE 3. Maximum likelihood estimates of fatty acid methyl ester and substrate utilization profile multiple logistic regression used to predict geographic region of origin of onion strains of Xanthomonas

\begin{tabular}{lcccrr}
\hline & \multicolumn{5}{c}{ Maximum likelihood estimates } \\
\cline { 2 - 6 } & df & Estimate $^{\mathrm{b}}$ & $\begin{array}{c}\text { Standard } \\
\text { error }\end{array}$ & Wald $\chi^{2}$ & $P>\chi^{2 \mathrm{c}}$ \\
\hline Parameter $^{\mathrm{a}}$ & 1 & -4.662 & 1.08 & 18.48 & $<0.0001$ \\
Intercept Barbados & 1 & -3.529 & 0.68 & 26.56 & $<0.0001$ \\
Intercept Brazil & 1 & -2.495 & 0.49 & 26.44 & $<0.0001$ \\
Intercept California & 1 & -1.670 & 0.39 & 18.56 & $<0.0001$ \\
Intercept Colorado & 1 & -1.260 & 0.35 & 12.68 & 0.0004 \\
Intercept Hawaii & 1 & 0.916 & 0.33 & 7.81 & 0.0052 \\
Intercept Japan & 1 & 1.704 & 0.38 & 19.71 & $<0.0001$ \\
Intercept South Africa & 1 & 2.166 & 0.43 & 24.97 & $<0.0001$ \\
Intercept Texas & 1 & 3.641 & 0.72 & 25.77 & $<0.0001$ \\
Factor 1 & 1 & 0.782 & 0.27 & 8.38 & 0.0038 \\
Factor 9 & 1 & 0.865 & 0.27 & 9.91 & 0.0016 \\
\hline
\end{tabular}

a Each equation is given by $Z=\beta_{0}+0.782$ (Factor 1$)+0.865$ (Factor 2 ), where $\beta_{0}$ is the cumulative logit intercept for each region; where Intercept Barbados $=-4.662$, Intercept Brazil (Barbados + Brazil $)=-3.529$, and Intercept Texas $=($ Barbados + Brazil $\ldots .+$ Texas $)=3.641$. The probability of group membership of a strain in a region $(\mathrm{Zi})$ is described by $p\left(R_{i}\right)=$ $e^{Z i} /\left(1+e^{Z i}\right)$, where $e$ is the natural logarithm and $p\left(R_{\text {Venezuela }}\right)=1-p\left(R_{\text {Texas }}\right)$. ${ }^{\mathrm{b}}$ Intercept estimate $=\beta_{0}$.

c Probability of obtaining a greater $\chi^{2}$ statistic than that observed if the null hypothesis is true. 
podis pv. allii surviving as weak pathogens or epiphytically. Greenhouse and field studies are in progress to quantitate the survival of $X$. axonopodis pv. allii between onion crops on dry bean and other hosts.

Resistance to commonly applied bactericides did not appear within the collection of strains included in this study. This is consistent with the findings of Paulraj and O'Garro (28) in Barbados.

Resistance to copper, zinc, and streptomycin has been widely reported in phytopathogenic bacteria $(6,7,17,23,24,39)$, and insensitivity is often conferred by resistance genes located on selftransmissible plasmids $(6,7,24,39)$. Xanthomonads are generally

\section{$\begin{array}{llllllll}20 & 40 & 60 & 80 & 100 & \text { BOX } & \text { ERIC } & \text { REP }\end{array}$}

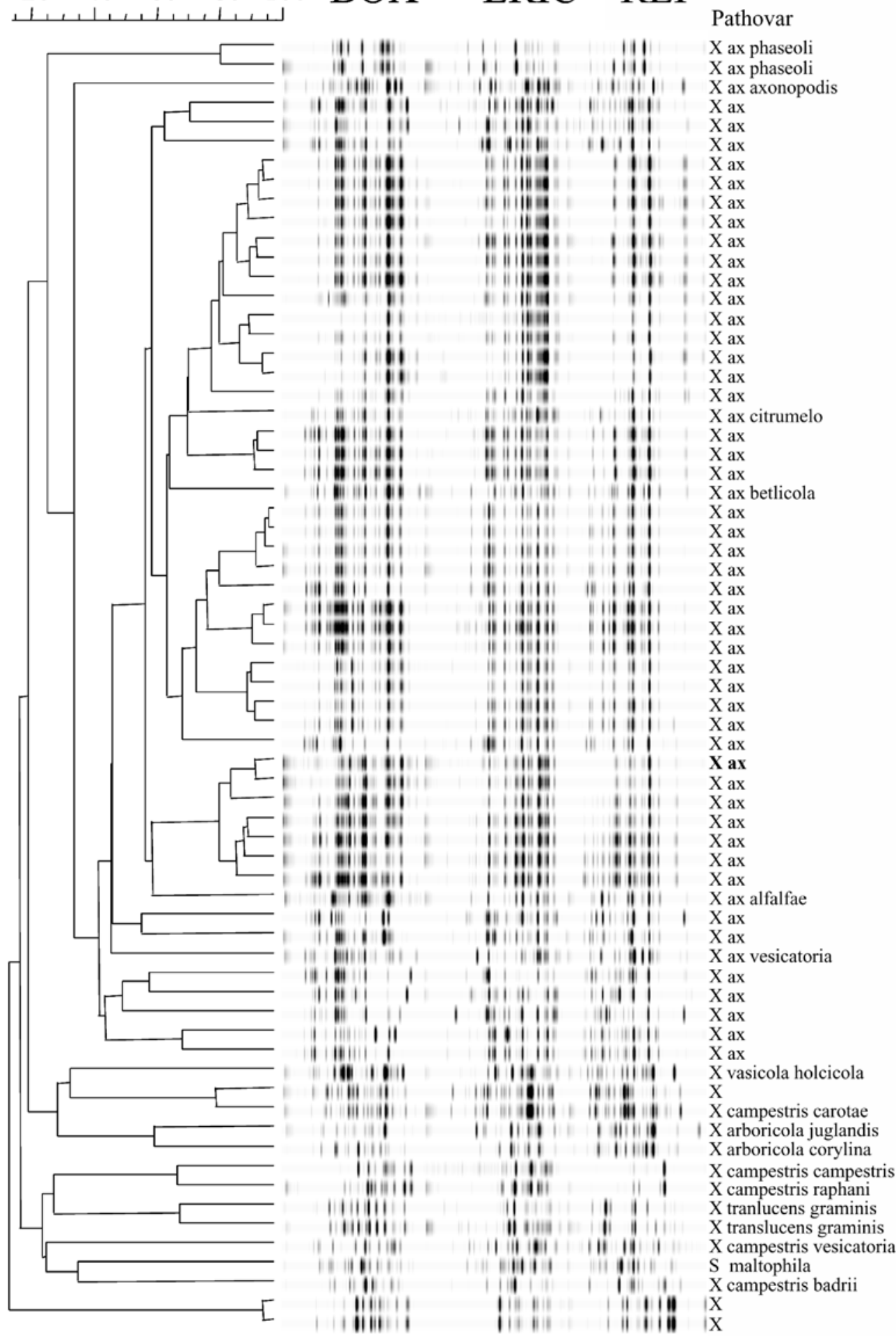

DNA homology

Strain group

49119

$19312-9$

TX-1a

TX-10

TX-3

A225-2

A $255-4$

A256-3

A206-5

A274-3

A551-3

A $2747 \mathrm{a}$

A206-2a

A94-lb

A118-2a

A554-3

A579-7

O177

49120

A206-2b

A229-1

A227-2

19047

Calandril-1

Calandril-3

Calon-5

Calon-1

JX 721

Xcu01-2

Xcu01-1

Xcu200-2

$\mathrm{O} 153$

O154

O130

O155

JX 727

MAFF 311173

MAFF 311174

MAFF 311179

MAFF 311175 .

MAFF 311176

MAFF 311177 .

MAFF 311178

11765

F2:22

TX-2c

11633

JV 594

JV 595

BAA 577

BAA 575

BAA 576

13461

TX-2b

10547

49083

19313

33913

49079

29088

29091

35937

13637

11672
A1890

A1889
.

9
9
9

9

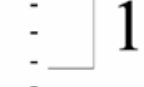

$:$

$-$

$-$

$-$

$: 2$

$-$

$\vdots$

9

$-$

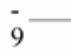

9

-

-

$-$

$-3$

\begin{tabular}{l}
- \\
- \\
- \\
- \\
- \\
- \\
- \\
- \\
- \\
- \\
- \\
- \\
- \\
\hline
\end{tabular}

$\square$

4

4

4
4

4
15

15

16

16

14

21
8

Fig. 4. Similarity among repetitive sequence based-polymerase chain reaction DNA fingerprints of onion Xanthomonas strains from various geographical areas and between other species and pathovars of Xanthomonas sp. DNA fingerprints were generated using primers corresponding to prokaryotic enterobacterial repetitive intergenic consensus (ERIC) sequences, repetitive extragenic palindromic (REP) sequences, and the BOXA subunit of the BOX element (BOX) and analyzed using the product-moment correlation coefficient $(r)$. DNA homology groups correspond to those reported by Rademaker et al. (30). The type strain of X. campestris pv. allii MAFF 311173 is noted in bold. Genotype groups 1 to 5 are noted with brackets. $\mathrm{X}=$ Xanthomonas, $\mathrm{X}$ ax $=X$. axonopodis, $\mathrm{S}$ maltophila $=$ Stenotrophomonas maltophilia, and $-=$ not known. 
considered resistant to copper, zinc, or streptomycin if they are able to grow on artificial media amended with 100 to $200 \mu \mathrm{g}$ of the bactericide per $\mathrm{ml}$, but resistance to streptomycin concentrations of $800 \mu \mathrm{g} / \mathrm{ml}$ or greater have been reported (24). Growers in Colorado and other onion-producing regions rely heavily on copper-based bactericides for disease suppression, and resistance may emerge with continued use (37), underscoring the need for an integrated pest management program to manage Xanthomonas leaf blight. The MIC of zinc was equal to or less than copper for all $X$. axonopodis pv. allii included in this study (data not shown), and zinc may be an effective bactericide to manage $X$. axonopodis pv. allii and delay copper resistance development. However, the relationship between the MICs determined in this study and sensitivity of bacterial cells under field conditions is unknown. Petri dish assays of bacterial sensitivity to copper, zinc, and streptomycin have been extensively used to detect bactericide resistance $(6,7,17,24,39)$, and in vitro sensitivity appears to be a suitable proxy for sensitivity under field conditions (22). The efficacy of zinc sprays is currently under investigation in field trials.

Fatty acid and substrate utilization profiling revealed significant intraspecific diversity. Cluster analysis revealed limited grouping of strains by geographical region of origin based on cellular fatty acid composition and, to a lesser extent, Biolog Microplate substrate utilization. However, the fatty acid and substrate utilization profiles were sufficiently variable among regions to allow for factor analysis and subsequent multiple logistic regression to generate a predictive model. The multiple logistic regression model developed in this study could correctly classify $69 \%$ of the strains included in this analysis into their geographical region of origin. Combining this model with rep-PCR-mediated DNA fingerprinting would provide a powerful tool for investi- gating dissemination of $X$. axonopodis pv. allii by seed transmission among onion production regions.

Identification of strains using the MIDI Aerobe database and Biolog version 4.1 database inconsistently identified strains. Fatty acid profiling identified the 49 strains of $X$. axonopodis pv. allii used in this study as 11 different Xanthomonas pathovars. Biolog identified the strains closest match as 10 different pathovars. Users of these systems are encouraged to create a new profile for $X$. axonopodis pv. allii if fatty acids or Biolog substrate utilization are to be used for identification.

The conserved rep-PCR genomic fingerprints within geographic locations suggest that the population structure is largely clonal within production areas. The tight phylogenetic cluster formed within a given production region suggests $X$. axonopodis pv. allii was introduced into these production regions in one or a few events, perhaps on contaminated seed $(3,34)$. The onion production regions considered in this study are sufficiently isolated that gene flow from other populations would be low and distinct clonal populations may have formed following genetic drift and selection of fit genotypes. The climates, cultivars, and production practices within the different onion production regions considered may have selected for fitness and adapted genotypes unique for each region. However, the signature bands of $X$. axonopodis pv. allii pathogenic on onion are conserved among strains, and the recent evolution of $X$. axonopodis pv. allii was revealed by the identical rDNA RFLP profiles and high sequence similarity of the nonconserved ITS region.

The relationship between $X$. axonopodis pv. allii and $X$. axonopodis pv. alfalfae, $X$. axonopodis pv. betlicola, $X$. axonopodis $\mathrm{pv}$. citrumelo, and $X$. axonopodis pv. vesicatoria and other DNA homology 9-2 strains remains unclear. Our study included a small

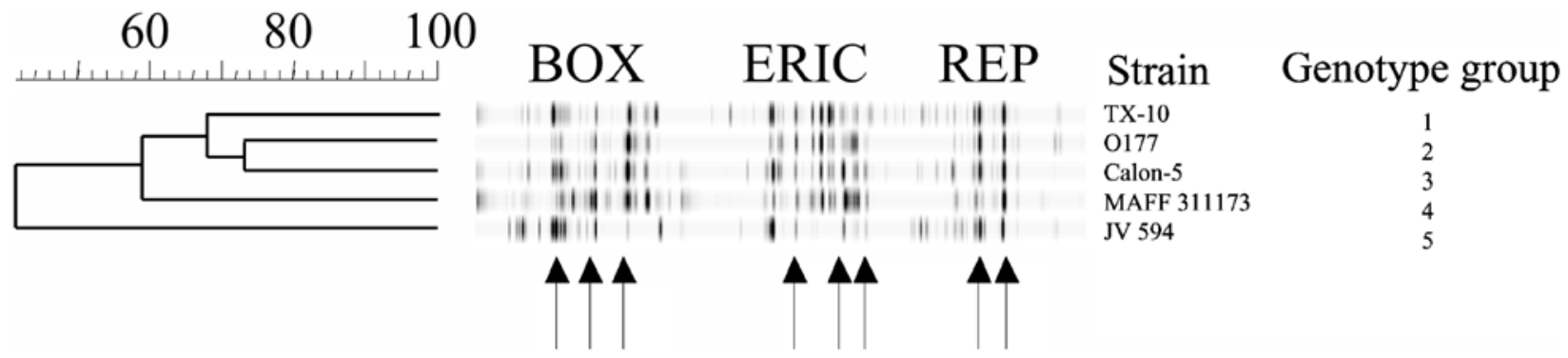

Fig. 5. Diversity of repetitive sequence based-polymerase chain reaction DNA fingerprints among onion Xanthomonas strains isolated from various geographical regions and representing different genotype groups. Arrows indicate DNA bands that are conserved across all strains pathogenic on onion. The scale indicates the product-moment correlation coefficient $(r)$. Strain MAFF 311173 is the type strain of $X$. campestris pv. allii. MAFF = Ministry of Agriculture, Forestry, and Fisheries GeneBank accession.

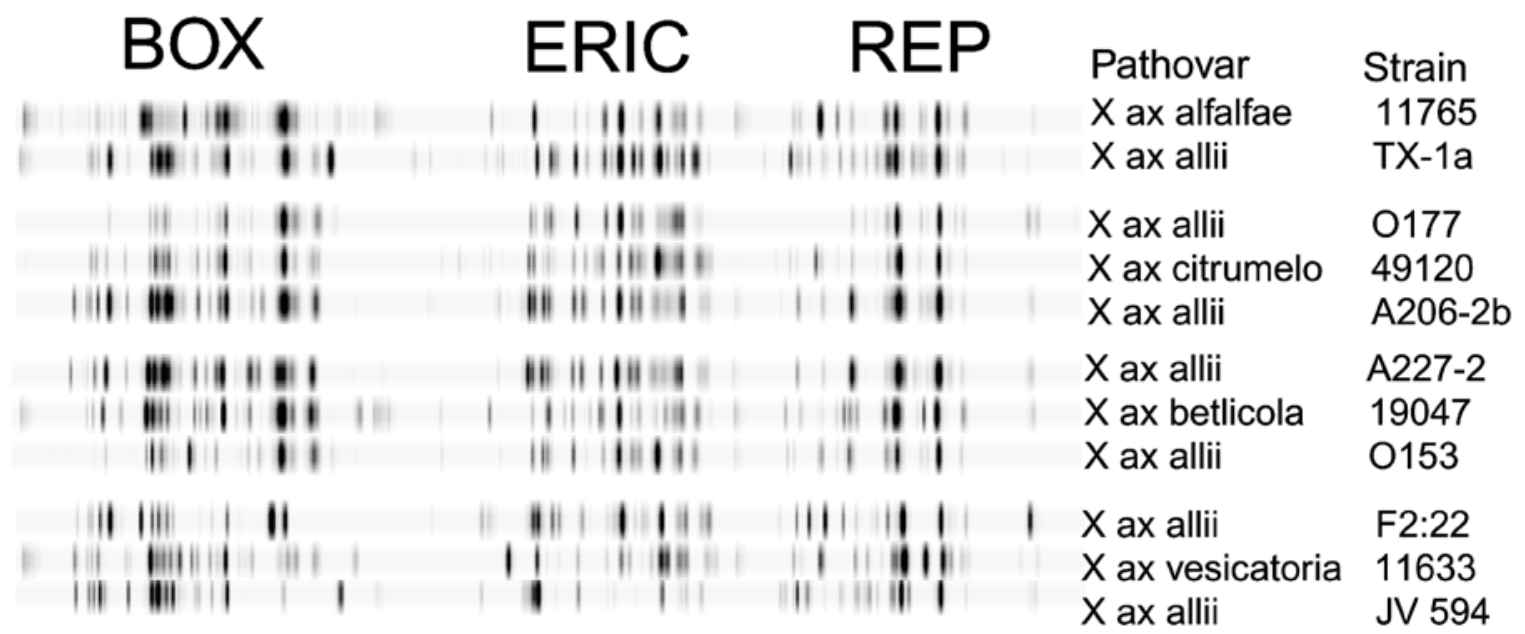

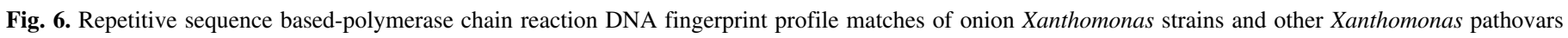
within DNA homology group 9-2. X ax = Xanthomonas axonopodis. 
subset of strains from each geographical region and few representative strains from other Xanthomonas species and pathovars. We are currently studying a larger collection of DNA homology group 9-2 strains to more fully describe the genetic and pathogenic relationships between these pathovars and $X$. axonopodis pv. allii.

The high level of genetic diversity within $X$. axonopodis $\mathrm{pv}$. allii is in stark contrast to many other DNA fingerprinting studies with Xanthomonas and other plant-pathogenic bacteria $(5,21,32)$. Louws et al. (20) found nearly identical rep-PCR DNA fingerprints within the subspecies of Clavibacter michiganensis. Genetic similarity within subspecies was greater than $80 \%$, but less than $40 \%$ between subspecies. The level of diversity within $X$. axonopodis pv. allii approaches that between Clavibacter subspecies. However, signature rep-PCR bands conserved within $X$. axonopodis pv. allii, identical rDNA RFLP profiles, and high ITS region sequence similarity do not suggest a polyphyletic population structure exists. Rademaker et al. (30) demonstrated that rep-PCR fingerprinting explains $81 \%$ of the variability in DNA:DNA homology and can be used to reflect true genotypic and phylogenetic relationships. $X$. axonopodis pv. allii rep-PCR fingerprints among strains were at least $40 \%$ similar, corresponding approximately to at least $70 \%$ DNA:DNA homology (30). Therefore, despite high levels of genetic diversity within the population, $X$. axonopodis pv. allii appears to constitute a single species. Genetic drift of geographically isolated populations could account for the observed diversity among rep-PCR DNA fingerprints. Knowledge of the population structure should aid in future epidemiological and ecological studies of $X$. axonopodis pv. allii.

Genetic diversity within $X$. axonopodis pv. allii may have important implications for resistance gene deployment and breeding. Host resistance to Xanthomonas leaf blight has only been reported in short day onion cultivars (27) and resistance appears to be associated with one or few genes. A race structure may exist within $X$. axonopodis pv. allii that could account for the variability in pathogenicity and virulence on pulse crops and other Allium. Studies are currently underway to further characterize genes involved in $X$. axonopodis pv. allii pathogenicity on onion and the existence of a population race structure.

\section{ACKNOWLEDGMENTS}

Funding for this research was provided by the Colorado Onion Association, Arkansas Valley Growers and Shippers Association, and USDA/ CSREES Crops at Risk Program Grant No. 2002-51100-01905, entitled "Integrated Management of Xanthomonas Leaf Blight of Onion by Cultural Practices, Disease Forecasting, and Biologically-Based Pesticides." We thank K. Morey for technical support and other researchers and organizations that provided strains for this study.

\section{LITERATURE CITED}

1. Altschul, S. F., Madden, T. L., Schaffer, A. A., Zhang, J. H., Zhange, Z., Miller, W., and Lipman, D. J. 1997. Gapped BLAST and PSI-BLAST: A new generation of protein database search programs. Nucleic Acids Res. 25:3389-3402.

2. Alvarez, A. M., Buddenhagen, I. W., Buddenhagen, E. S., and Domen, H. Y. 1978. Bacterial blight of onion, a new disease caused by Xanthomonas sp. Phytopathology 68:1132-1136.

3. Audy, P., Laroche, A., Saindon, G., Huang, H. C., and Gilbertson, R. L. 1994. Detection of the bean common blight bacteria Xanthomonas campestris pv. phaseoli and X. c. phaseoli var. fuscans, using the polymerase chain reaction. Phytopathology 84:1185-1192.

4. Ausubel, F. M., Brent, R., Kingston, R. E., Moore, D. D., Seidman, J. G., Smith, J. A., and Struhl, K. 1998. Current Protocols in Molecular Biology. John Wiley \& Sons, Hoboken, NJ.

5. Barak, J. D., and Gilbertson, R. L. 2003. Genetic diversity of Xanthomonas campestris pv. vitians, the casual agent of bacterial leafspot of lettuce. Phytopathology 93:596-603.

6. Bender, C. L., and Cooksey, D. A. 1986. Indigenous plasmids in Pseudomonas syringae pv. tomato: Conjugative transfer and role in copper resistance. J. Bacteriol. 165:534-541.
7. Bender, C. L., Malvick, D. K., Conway, K. E., George, S., and Pratt, P. 1990. Characterization of pXV10A, a copper resistance plasmid in Xanthomonas campestris pv. vesicatoria. Appl. Environ. Microbiol. 56: 170-175.

8. Bowen, P., Gibbs, H. A., and O'Garro, L. W. 1996. Garlic, chives, shallot, and leek are alternative hosts to Xanthomonas campestris, the pathogen of leaf blight of onion. Proc. Int. Congr. Plant Pathol. 7:696.

9. Cubero, J., and Graham, J. H. 2002. Genetic relationship among worldwide strains of Xanthomonas causing canker in citrus species and design of new primers for their identification by PCR. Appl. Environ. Microbiol. 86:1257-1264.

10. Dye, D. W., Bradbury, J. F., Goto, M., Hayward, A. C., Lelliott, R. A., and Schroth, M. N. 1980. International standards for naming pathovars of phytopathogenic bacteria and a list of pathovar names and pathotype strains. Rev. Plant Pathol. 59:153-160.

11. Fenselau, S., Balbo, I., and Bonas, U. 1992. Determinants of pathogenicity in Xanthomonas campestris pv. vesicatoria are related to proteins involved in secretion in bacterial pathogens of animals. Mol. Plant-Microbe Interact. 5:390-396.

12. Gent, D. H., Schwartz, H. F., Ishimaru, C. A., Louws, F. J., Cramer, R. A., and Lawrence, C. B. 2002. Polyphasic characterization of Xanthomonas campestris from onion. Page 48 in: Proc. 2002 Natl. Allium Res. Conf., Natl. Allium Res. Conf., Pasco, WA.

13. Hauben, L., Vauterin, L., Swings, J., and Moore, E. R. B. 1997. Comparison of $16 \mathrm{~S}$ ribosomal DNA sequences of all Xanthomonas species. Int. J. Syst. Bacteriol. 47:328-335.

14. Isakeit, T., Miller, M. E., Barnes, L. W., Dickstein, E. R., and Jones, J. B. 2000. First report of leaf blight of onion caused by Xanthomonas campestris in the continental United States. Plant Dis. 84:201.

15. Jensen, M. A., Webster, J. A., and Straus, N. 1993. Rapid identification of bacteria on the basis of polymerase chain reaction-amplified ribosomal DNA spacer polymorphisms. Appl. Environ. Microbiol. 59:945-952.

16. Kadota, I., Uehara, K., Shinohara, H., and Nishiyama, K. 2000. Bacterial blight of Welsh onion: A new disease caused by Xanthomonas campestris pv. allii pv. nov. J. Gen. Plant Pathol. 66:310-315.

17. Lee, Y., Hendson, M., Panopoulos, N. J., and Schroth, M. N. 1994. Molecular cloning, chromosomal mapping, and sequence analysis of copper resistance genes from Xanthomonas campestris pv. juglandis: Homology with small blue copper proteins and multicopper oxidase. J. Bacteriol. 176:173-188.

18. Leite, R. P., Jr., Minsavage, G. V., Bonas, U., and Stall, R. E. 1994. Detection and identification of phytopathogenic Xanthomonas strains by amplification of DNA sequences related to the hrp genes of Xanthomonas campestris pv. vesicatoria. Appl. Environ. Microbiol. 60:1068-1077.

19. Louws, F. J., Bell, J., Medina-Mora, C. M., Smart, C. D., Opgenorth, D., Ishimaru, C. A., Hausbeck, M. K., de Bruijin, F. J., and Fulbright, D. W. 1998. rep-PCR-mediated genomic fingerprinting: A rapid and effective method to identify Clavibacter michiganensis. Phytopathology 88:862-868.

20. Louws, F. J., Fulbright, D. W., Stephens, C. T., and de Bruijn, F. J. 1994. Specific genomic fingerprints of phytopathogenic Xanthomonas and Pseudomonas pathovars and strains generated with repetitive sequences and PCR. Appl. Environ. Microbiol. 60:2286-2295.

21. Louws, F. J., Fulbright, D.W., Stephens, C. T., and de Bruijin, F. J. 1995. Differentiation of genomic structure by rep-PCR fingerprinting to rapidly classify Xanthomonas campestris pv. vesicatoria. Phytopathology 85:528-536.

22. Mahuku, G., Carlos, J., Henriquez, M. A., and Cuasquer, J. 2002. Diversity among Xanthomonas axonopodis pv. phaseoli strains from different geographical areas and pathogenic on common bean. (Abstr.) Phytopathology 92(suppl.):S50.

23. Marco, G. M., and Stall, R. E. 1983. Control of bacterial spot of pepper initiated by strains of Xanthomonas campestris pv. vesicatoria that in differ in sensitivity to copper. Plant Dis. 67:779-781.

24. Minsavage, G. V., Canteros, B. I., and Stall, R. E. 1990. Plasmidmediated resistance to streptomycin in Xanthomonas campestris pv. vesicatoria. Phytopathology 80:719-723.

25. National Committee for Clinical Laboratory Standards. 2000. Methods for Antimicrobial Susceptibility Tests for Bacteria that Grow Aerobically. 5th ed. Approved Standard M7-A5. NCCLS, Wayne, PA.

26. Nunez, J. J., Gilbertson, R. L., Meng, X., and Davis, R. M. 2002. First report of Xanthomonas leaf blight of onion in California. Plant Dis. $86: 330$.

27. O'Garro, L. W., and Paulraj, L. P. 1997. Onion leaf blight caused by Xanthomonas campestris: Alternative hosts and resistant onion genotypes. Plant Dis. 81:978-982.

28. Paulraj, L., and O'Garro, L. W. 1992. Aspects of the epidemiology of a leaf blight of onion in Barbados. Pages 89-96 in: Proc. Annu. Conf. Barbados Soc. Technol. Agric., 10th. Barbados, West Indies.

29. Paulraj, L., and O'Garro, L. W. 1993. Leaf blight of onions in Barbados caused by Xanthomonas campestris. Plant Dis. 77:198-201. 
30. Rademaker, J. L. W., Hoste, B., Louws, F. J., Kersters, K., Swings, J., Vauterin, L., Vauterin, P., and de Bruijn, F. J. 2000. Comparison of AFLP and rep-PCR genomic fingerprinting with DNA-DNA homology studies: Xanthomonas as a model system. Int. J. Syst. Bacteriol. 50:665-677.

31. Rademaker, J. L. W., Louws, F. J., and de Bruijn, F. J. 1999. Computer assisted pattern analysis of electrophoretic fingerprints and database construction. Pages 1-33 in: Molecular Microbial Ecology Manual. A. D. L. Akkermans, J. D. van Elsas, and F. J. de Bruijn, eds. Kluwer Academic Publishers, Dordrecht, the Netherlands.

32. Roberts, P. D., Hodge, N. C., Bouzar, H., Jones, J. B., Stall, R. E., Berger, R. D., and Chase, A. R. 1998. Relatedness of strains of Xanthomonas fragariae by restriction fragment length polymorphism, DNA-DNA reassociation, and fatty acid analyses. Appl. Environ. Microbiol. 64:39613965 .

33. Roumagnac, P., Gagnevin, L., Gardan, L., Sutra, L., Manceau, C., Dickstein, E. R., Jones, J. B., Rott, P., and Pruvost, O. Polyphasic characterization of xanthomonads isolated from onion, garlic and Welsh onion (Allium spp.) and their relatedness to different Xanthomonas species. Int. J. Syst. Evol. Microbiol. (In Press.)

34. Roumagnac, P., Gagnevin, L., and Pruvost, O. 2000. Detection of Xanthomonas sp., the causal agent of onion bacterial blight, in onion seeds using a newly developed semi-selective isolation medium. Eur. J. Plant Pathol. 106:867-877.

35. Sanders, F. H., Langston, D. B., Brock, J. H., Gitaitis, R. D., Curry, D. E., and Torrance, R. L. 2003. First report of a leaf blight of onion caused by Xanthomonas spp. in Georgia. Plant Dis. 87:749.
36. Schwartz, H. F., and Otto, K. 2000. First report of a leaf blight of onion by Xanthomonas campestris in Colorado. Plant Dis. 84:922.

37. Schwartz, H. F., and Otto, K. J. 1998. Onion bacterial disease management in Colorado. Pages 214-218 in: Proc. 1998 Natl. Onion (and other Allium) Res. Conf.

38. Serfontein, J. J. 2001. Xanthomonas blight of onion in South Africa. Plant Dis. 85:442.

39. Sundin, G. W., Jones, A. L., and Fulbright, D. W. 1989. Copper resistance in Pseudomonas syringae from cherry orchards and its associated transfer in vitro and in planta with a plasmid. Phytopathology 79:861-865.

40. Thomas, W. D., Jr., and Weinhold, A. R. 1953. Xanthomonas striaformans, a new bacterial pathogen of onion. J. Colo.-Wyo. Acad. Sci. $4: 22$.

41. Vauterin, L., Hoste, B., Kersters, K., and Swings, K. 1995. Reclassification of Xanthomonas. Int. J. Syst. Bacteriol. 45:472-489.

42. Vauterin, L., Yang, P., and Swings, J. 1996. Utilization of fatty acid methyl esters for the differentiation of new Xanthomonas species. Int. J. Syst. Bacteriol. 46:298-304

43. Verniere, C., Pruvost, O., Civerolo, E. L., Gambin, O., JacquemoudCollet, J. P., and Luisetti, J. 1993. Evaluation of the Biolog substrate utilization system to identify and assess metabolic variation among strains of Xanthomonas campestris pv. citri. Appl. Environ. Microbiol. 59:243-249.

44. Weller, D. M., and Saettler, A. W. 1978. Rifampin-resistant Xanthomonas phaseoli var. fuscans and Xanthomonas phaseoli: Tools for field study of bean blight bacteria. Phytopathology 68:778-781. 